\title{
Egg production, hatching rates, and abbreviated larval development of Campylonotus vagans Bate, 1888 (Crustacea: Decapoda: Caridea), in subantarctic waters
}

\author{
Sven Thatje ${ }^{\mathrm{a}, *}$, Gustavo A. Lovrich ${ }^{\mathrm{b}}$, Klaus Anger ${ }^{\mathrm{c}}$ \\ a Alfred Wegener Institute for Polar and Marine Research, PO Box 120 161, D-27515 Bremerhaven, Germany \\ ${ }^{\mathrm{b}}$ Consejo Nacional de Investigaciones Cientificas y Técnica, Centro Austral de Investigaciones Cientificas, \\ CC 92, Ushuaia, Tierra del Fuego, Argentina \\ ${ }^{\mathrm{c}}$ Biologische Anstalt Helgoland, Stiftung Alfred Wegener Institute for Polar and Marine Research, \\ Helgoland, Germany
}

Received 1 January 2003; received in revised form 23 May 2003; accepted 1 September 2003

\begin{abstract}
Early life history patterns were studied in the caridean shrimp, Campylonotus vagans Bate, 1888, from the subantarctic Beagle Channel (Tierra del Fuego). As a consequence of very large egg size (minimum $1.4 \mathrm{~mm}$ ), fecundity was low, ranging from 83 to 608 eggs per female (carapace length [CL] 11-22.5 mm). Egg size increased continuously throughout embryonic development, reaching prior to hatching about $175 \%$ of the initial diameter. Due to low daily numbers of larval release, hatching of an egg batch lasted for about 2-3 weeks. The complete larval and early juvenile development was studied in laboratory cultures fed with Artemia sp. nauplii. At $7.0 \pm 0.5{ }^{\circ} \mathrm{C}$, development from hatching to metamorphosis lasted for about 6 weeks. It comprised invariably two large zoeal stages and one decapodid, with mean stage durations of 12,17 , and 15 days, respectively. Larvae maintained without food survived on average for 18 days (maximum: 29 days), but did not reach the moult to the zoea II stage. Size increments at ecdysis were low in all larval stages $(2.1-$ $3.9 \%)$, indicating partial utilisation of internal energy reserves. A clearly higher increment $(14 \%)$ was observed in the moult from the first to the second juvenile stage. Low fecundity, large size of eggs and larvae, an abbreviated mode of larval development, high larval survival rates during absence of food, demersal behaviour of the early life history stages, and an extended hatching period with low daily release rates are interpreted as adaptations to conditions typically prevailing in subantarctic regions, namely low temperatures (causing long durations of development) in
\end{abstract}

* Corresponding author. Tel.: +49-471-4831-1315; fax: +49-471-4831-1149.

E-mail address: sthatje@awi-bremerhaven.de (S. Thatje). 
combination with a pronounced seasonality in plankton production (i.e., short periods of food availability).

(C) 2003 Elsevier B.V. All rights reserved.

Keywords: Abbreviated larval development; Decapoda; Fecundity; Hatching; Mortality

\section{Introduction}

Several species of caridean shrimps have developed strong life history adaptations to both latitudinally changing conditions of food and temperature (for reviews, see Clarke, 1982, 1987, 1993a). Among the most conspicuous adaptations, this includes an increasing egg size with increasing latitude and decreasing average water temperature, associated with changes in the biochemical composition of eggs, and often reduced fecundity (Gorny et al., 1992; Wehrtmann and Kattner, 1998; Wehrtmann and Lardies, 1999; Anger et al., 2002). As an additional latitudinal trend, larval size at hatching appears to increase, while the number in larval instars and the degree of morphological variability tend to decrease (cf. Wehrtmann and Albornoz, 1998; Thatje and Bacardit, 2000). Low temperatures at high latitudes have been observed to enhance not only larval development time, but also slower growth and lower mortality as compared with boreal species (Clarke and Lakhani, 1979; Arntz et al., 1992; Gorny et al., 1993).

The diversity of decapod crustaceans is comparably low in polar regions (Yaldwyn, 1965; Abele, 1982; Briggs, 1995). In the caridean shrimps, there is a strong decline in species diversity from the subantarctic (Gorny, 1999) to Antarctic waters (see Yaldwyn, 1965; Kirkwood, 1984; Tiefenbacher, 1990), with only five representatives remaining on the high Antarctic Weddell Sea shelf (Gorny, 1999).

The family Campylonotidae consists of four known subantarctic and one Antarctic representative (Gorny, 1999; Thatje, 2003). The species of this family show a wide bathymetric distribution, ranging from the shallow sublittoral to the deep sea (Thatje and Lovrich, 2003). Within the subantarctic Magellan Region (South America), the two species Campylonotus vagans Bate, 1888, and Campylonotus semistriatus Bate, 1888, are known to occur in the Argentine Beagle Channel $\left(54^{\circ} 53 \mathrm{~S}, 68^{\circ} 17 \mathrm{~W}\right.$, Fig. 1). $C$. vagans is associated with the shallow sublittoral fauna and can be found as by-catch of the dominating galatheid crab Munida subrugosa (Pérez-Barros et al., in press; Tapella et al., 2002). C. semistriatus Bate, 1888, in contrast, is more abundant in the sublittoral below $100 \mathrm{~m}$ depth (Wehrtmann and Lardies, 1996).

Little is generally known about the early life history of campylonotid shrimps. Protandrous hermaphroditism is assumed to be a typical trait in this family (Yaldwyn, 1966; Torti and Boschi, 1973), but this has not been confirmed for all species. The Campylonotidae shows apparently an abbreviated mode of larval development (Pike and Williamson, 1966; Thatje et al., 2001). However, a complete description of larval and early juvenile morphology is only available for $C$. vagans (Thatje et al., 2001; Thatje and Lovrich, 2003).

The knowledge of early life history patterns in shrimps from high latitudes and, in particular, from subantarctic waters, is scarce. In the present study, we document 


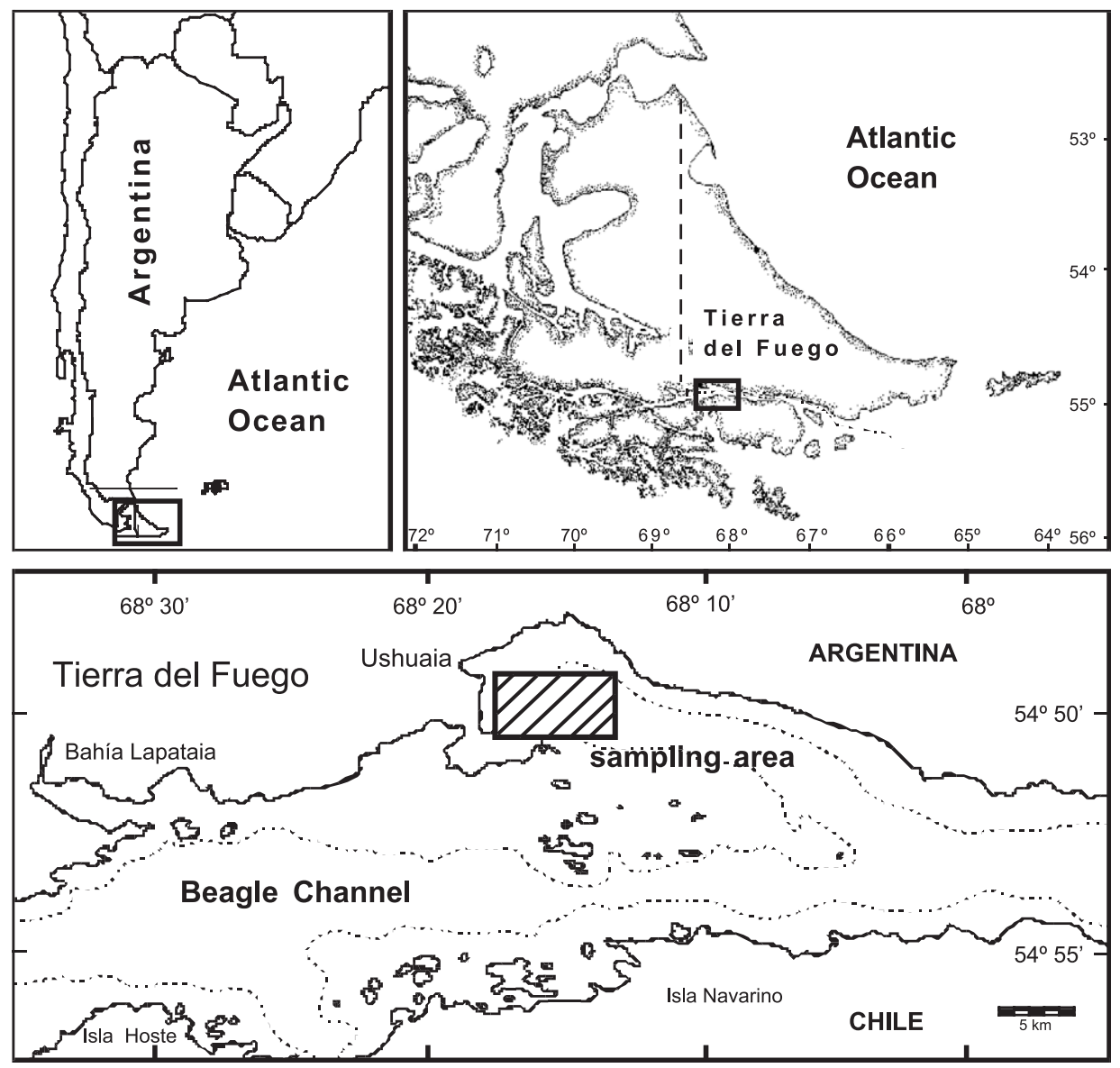

Fig. 1. Sampling location of C. vagans in the subantarctic Beagle Channel, South America.

laboratory observations on fecundity, egg size, hatching, as well as on larval and early juvenile development in the caridean shrimp C. vagans from subantarctic waters. The early life history of this species is discussed in relation to ecological conditions prevailing in the cold to temperate subantarctic region of South America.

\section{Materials and methods}

\subsection{Sampling of ovigerous females}

Ovigerous $C$. vagans were caught in September 2001 from about 15 to $30 \mathrm{~m}$ depth in the Beagle Channel (54 $53^{\prime} \mathrm{S}, 68^{\circ} 17^{\prime} \mathrm{W}$, Fig. 1) using an inflatable dinghy equipped with an epibenthic trawl (1.7 m mouth width, net with $1 \mathrm{~cm}$ mesh size), which was especially designed to be operated from a small boat (Tapella et al., 2002). Additional egg-carrying 
females (fixed in 3-4\% formalin buffered with hexamethylenetetramine) were obtained from bottom trawls taken during the expedition "Cimar Fiordo III" on board the Chilean vessel "Vidal Gormaz" to the Magellan region, the Straits of Magellan (53 $\mathrm{S})$ and the Beagle Channel $\left(55^{\circ} \mathrm{S}\right)$ in October 1997 (Thatje and Mutschke, 1999). Both regions show a comparable temperature regime ranging from about 4 to $9{ }^{\circ} \mathrm{C}$ in winter and summer, respectively (Lovrich, 1999; Tapella et al., 2002).

\subsection{Maintenance of ovigerous females}

Maintenance of ovigerous females and rearing of larvae took place in the local institute "Centro Austral de Investigaciones Científicas" (CADIC) in Ushuaia, Tierra del Fuego (Argentina), under constant conditions of temperature $\left(7.0 \pm 0.5{ }^{\circ} \mathrm{C}\right)$, salinity $(30 \% 0)$, and a 12:12 h light/dark rhythm. The ovigerous shrimps were kept individually in tanks (minimum 301 water content) with permanent seawater flow from a closed circulation filter system. Food (commercial TETRA AniMin pellets for aquaristics, TetraWerke, Germany) was given twice a week.

\subsection{Rearing of larvae and juveniles}

Hatched larvae were sampled each $24 \mathrm{~h}$ and collected from the bottom of the aquaria using long glass pipettes. Each day, randomly selected larvae were transferred to individual rearing cups with about $100 \mathrm{ml}$ seawater. They were checked daily for dead or moulted individuals. Every second day, water was changed and food (Artemia sp. nauplii; Argent Chemical Laboratories, USA) was supplied. In an additional rearing, larvae from the same female $(N=48)$ were kept under starvation condition.

The appearance of exuvia and visual observation of conspicuous morphological differences were used to distinguish between the different stages of larval and juvenile development. The zoea II can be easily distinguished from the previous stage by the presence of well-developed external uropods (see Thatje et al., 2001), while the decapodid is characterised by fully developed pereiopods bearing reduced exopods and complete formation of the telson (Thatje and Lovrich, 2003).

\subsection{Estimation of fecundity, measurements of eggs and larvae}

The term fecundity is herein considered as the number of eggs per clutch. For the calculation of clutch size/number of eggs, pleopods with attached eggs were removed from each female by cutting the pleopodal base. Eggs were directly enumerated, due to low fecundity in $C$. vagans. Fecundity in the individually kept females for the study of hatching patterns and larval development was inferred from the daily number of hatched larvae and egg losses.

The embryonic state of the eggs was divided into five stages; the first three were classified according to the criteria provided by Wehrtmann and Kattner (1998): stage I: eggs recently produced, uniform yolk, no eye pigments visible; stage II: eye pigments barely visible; stage III: eyes clearly visible and fully developed, abdomen free. Additionally, two later developmental stages were distinguished: stage IV: eggs elongate, 
Table 1

Average egg lengths of developing embryos (stage I to V, $N=25$ each) of $C$. vagans from the subantarctic Beagle Channel, South America

\begin{tabular}{lll}
\hline & Egg length $(\mathrm{mm})$ & S.D. \\
\hline Stage I & 1.40 & 0.05 \\
Stage II & 1.45 & 0 \\
Stage III & 1.60 & 0.05 \\
Stage IV & 1.65 & 0.10 \\
Stage V before hatching & 2.45 & 0.05 \\
\hline
\end{tabular}

appendages free, prezoea close to hatching; stage V: strongly elongate, appendages free, not covered by the abdomen anymore, setae of tail fan elongate. Stage $\mathrm{V}$ eggs were released from the female pleopods during the hatching of larvae.

After fixation of larvae in $4 \%$ buffered formalin, larval carapace length (CL) and total length (TL) were measured from the base of the rostrum between the eyes to the posterior dorsal margin of the carapace, and to the posterior margin of the telson, respectively. All lengths in eggs ( $N=25$ in each stage) and larvae (see Table 2) were measured to the nearest 0.05 and $0.01 \mathrm{~mm}$, respectively, using an eyepiece micrometer and a Zeiss stereomicroscope.

\subsection{Statistical treatments}

The relationship between fecundity and female size was analyzed with a linear regression analysis (Sokal and Rohlf, 1995) previously log-transforming data to achieve linearity.

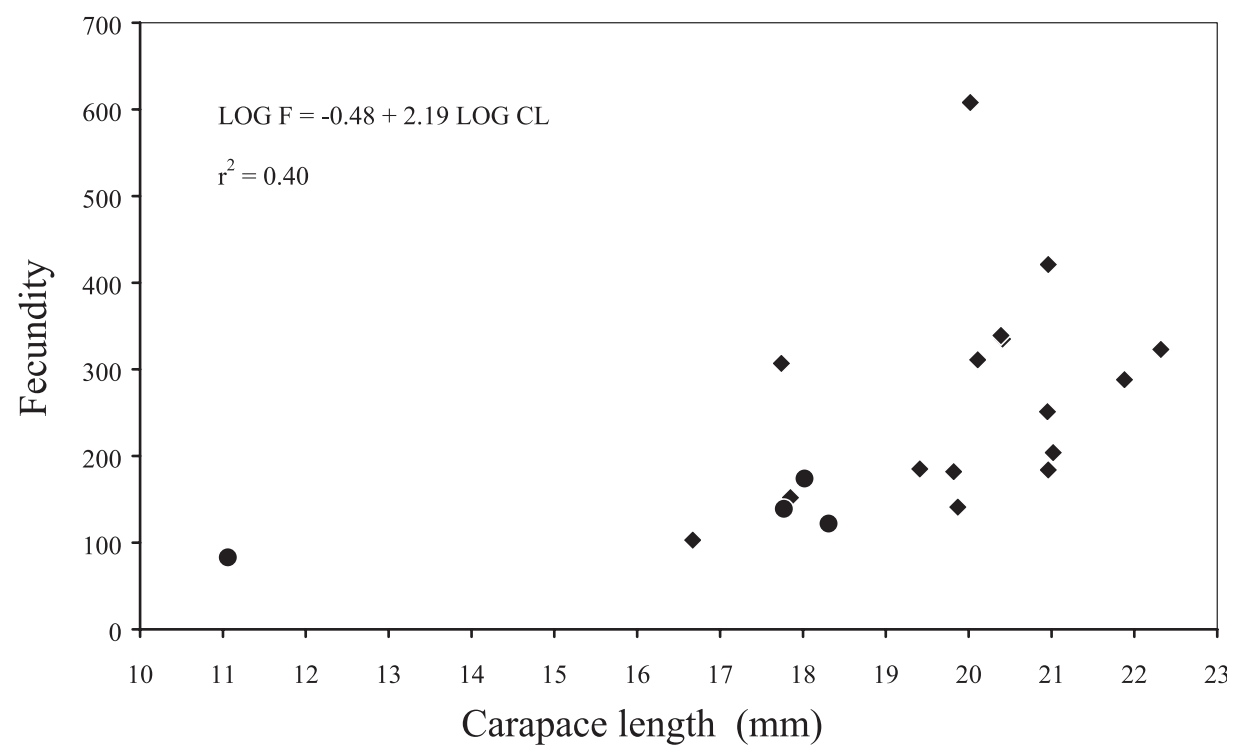

Fig. 2. Female fecundity in C. vagans from the subantarctic Beagle Channel, South America. Round dots indicate females maintained for larval development studies. 

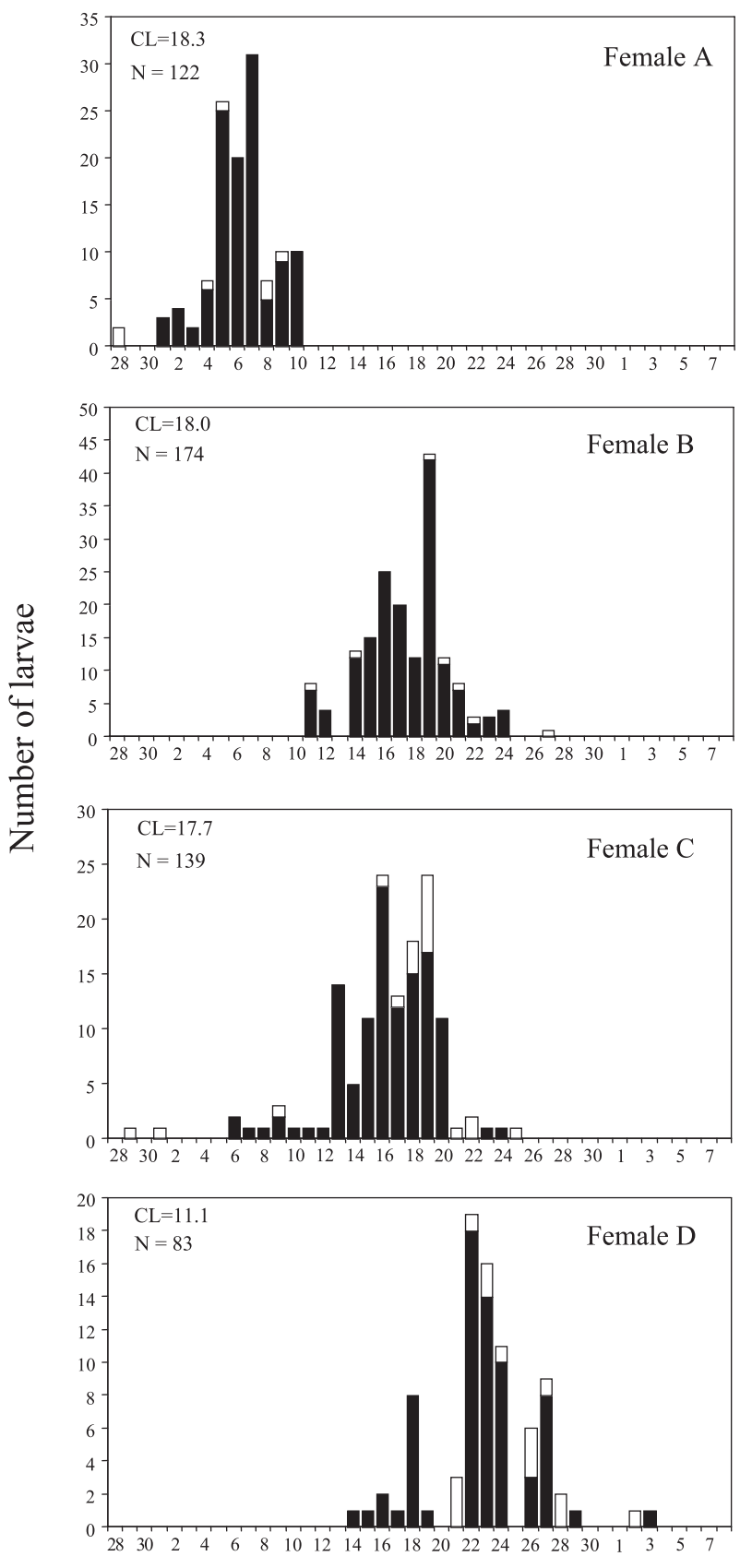

October

Date

Fig. 3. Daily hatching rates in C. vagans from the subantarctic Beagle Channel in 2001. Bare bars represent the egg losses. 
Significant differences in egg sizes among the different stages were tested using a one-way ANOVA (Sokal and Rohlf, 1995). Assumptions of homoscedasticity and normality were tested with Bartlett's and Kolmogorov-Smirnov tests, respectively. For the ANOVA, we pooled the egg size data of stages I and II because of strong similarity and no variability in stage II (Table 1).

\section{Results}

\subsection{Fecundity and developmental increase in egg sizes}

Fecundity of $C$. vagans from the Beagle Channel was low, varying from 83 to 608 eggs per female $(N=20$, Fig. 2$)$. In spite of high individual variability, the log number of eggs increased significantly with $\log$ female size, and followed the linear function: $\log N$ eggs $=2.2 \log \mathrm{LC}-0.5$ (Fig. $2 ; F_{\text {regress }}=13.5 ; P=0.002$ ).

During embryonic development from stages I to IV, we observed a continuous increase in egg size (Table 1). Eggs prior to hatching (stage V) were significantly larger than those in earlier stages (stages I + II combined; $F=9061.7 ; P<0.001$ ), reaching eventually $175 \%$ of the initial (stage I) size.

\subsection{Hatching pattern and larval development}

The first larvae hatched at night, about a fortnight after the capture of ovigerous females, showing a strong demersal behaviour. Nocturnal hatching of larvae occurred through an extended period varying from 10 to 21 days. Normally, about $4-17 \%$ of the total egg clutch hatched during single nights, exceptionally up to $25 \%$ (see female A, Fig. 3 ). The amount of eggs lost during hatching usually corresponded to about $0-15 \%$ of the respective nocturnal hatching rate of larvae. In some cases, however, egg losses were very high, and corresponded to about $35-50 \%$ of the respective nocturnal hatching rate of larvae (females C, D, Fig. 3). In almost all cases, stage V eggs were lost, indicating prezoeae close to hatching.

The development from hatching to metamorphosis lasted about 6 weeks. It comprised two zoeal stages and one decapodid, with mean durations of 12, 17, and 15 days, respectively (Table 2). Most of this time was spent in the zoea II stage, which showed also

Table 2

Average lengths (TL, CL) and developmental times in larvae and early juveniles of C. vagans from the subantarctic Beagle Channel, South America

\begin{tabular}{llll}
\hline & Total length, TL & Carapace length, CL & Developmental time (days) \\
\hline Zoea I & $4.76(0.09 ; 29)$ & $1.18(0.05 ; 29)$ & $11.7(0.89 ; 32)$ \\
Zoea II & $4.86(0.09 ; 13)$ & $1.12(0.06 ; 13)$ & $16.7(4.2 ; 15)$ \\
Decapodid & $5.15(0.04 ; 21)$ & $1.25(0.04 ; 21)$ & $15.3(2.3 ; 6)$ \\
Juvenile I & $5.35(0.07 ; 8)$ & $1.45(0.07 ; 8)$ & $19.5(0.7 ; 2)$ \\
Juvenile II & $6.1(0.3 ; 2)$ & $1.55(0.05 ; 2)$ & \\
\hline
\end{tabular}

In brackets: standard deviation; $N$. 
the highest variability in development time (Table 2). Highest mortality was found at metamorphosis from the zoea II to the decapodid stage (about 60\%), and during the subsequent moult to the first juvenile stage (67\%; Fig. 4A). The larvae were large already

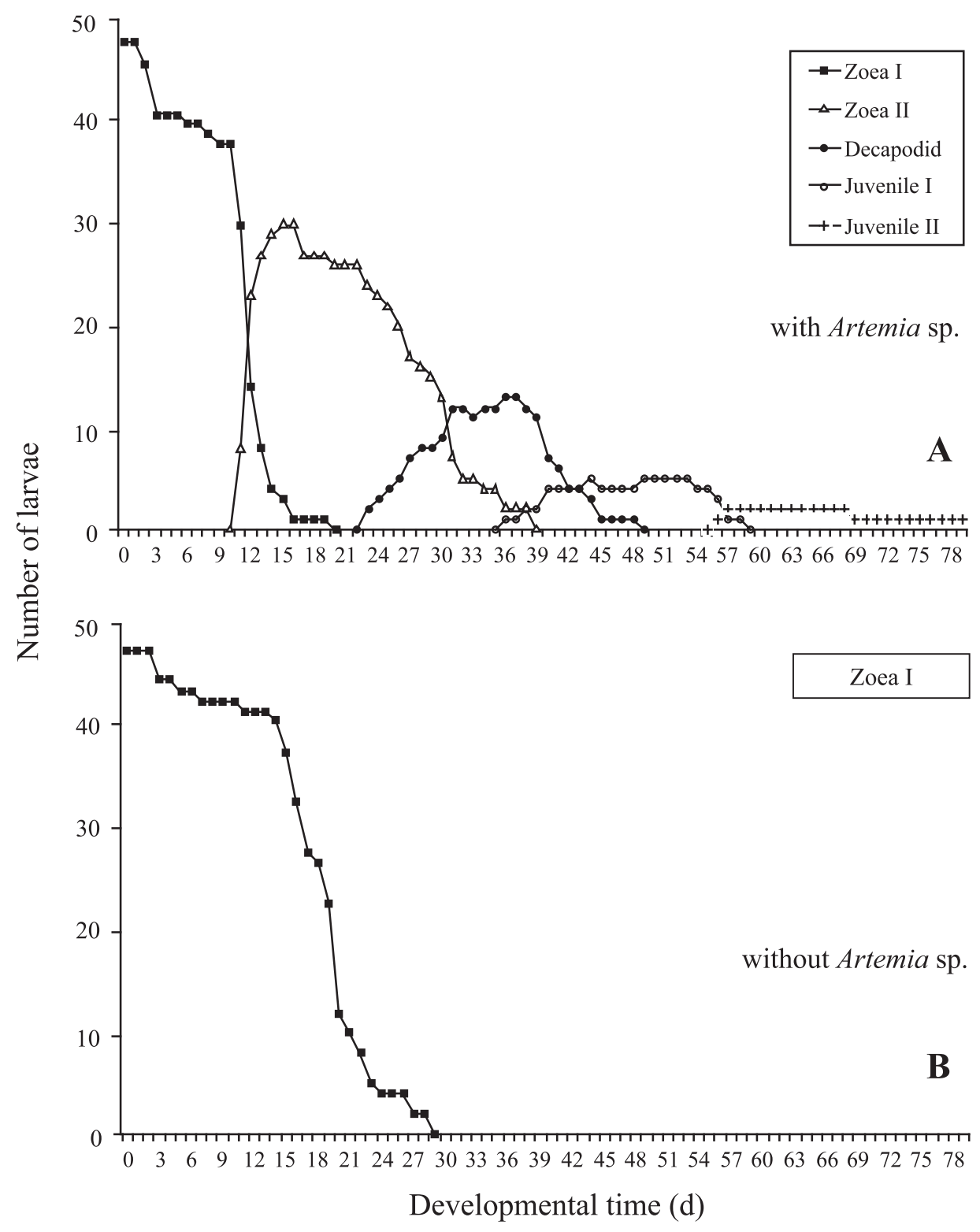

Fig. 4. C. vagans, changes in the number of larvae throughout larval development (A) larvae and early juveniles with food (Artemia sp.) and (B) zoea I without food (Artemia sp.). 
at hatching (average $\mathrm{TL}=4.8 \mathrm{~mm}$; Table 2), but in the subsequent moults, they showed low growth rates, with TL increments of $2.1 \%, 3.4 \%$ and $3.9 \%$, respectively. The moult of the first to the second juvenile stage, by contrast, was accompanied by an increment in size of about $14 \%$.

Larvae kept under starvation conditions (without Artemia sp.) did not reach the moult to the zoea II stage. The average survival time lasted 18 days, although some larvae survived for up to almost 1 month (29 days), i.e., about three times longer than the average stage duration in fed zoeae (Fig. 4A,B).

\section{Discussion}

The Campylonotidae shows protandrous hermaphroditism, which is typical of caridean shrimps (Bauer, 1989, and references therein) and has been interpreted as an energetic life history response to low temperatures in high latitudes (Yaldwyn, 1966; Torti and Boschi, 1973). We suggest sex reversal in C. vagans to occur at a body size of approximately $11 \mathrm{~mm}$ $\mathrm{CL}$, which corresponds to the size of the smallest ovigerous female found in the present study (Fig. 2). However, further investigations are needed to define exact size of sex reversal in the Campylonotidae. Most females carrying eggs had a CL of $>16.5 \mathrm{~mm}$ (Fig. 2), and, therefore, the smallest ovigerous female found may not be representative for the population.

Extended hatching periods in decapods of high latitudes were recently discussed to be a mechanism for synchronising larval occurrence with short periods of primary production/ food availability in high latitudes (for a detailed discussion, see Thatje et al., 2003a). Extended hatching periods may also allow for avoiding predation on the small offspring (see Thatje et al., 2003a).

C. vagans showed low fecundity (compare with Reid and Corey, 1991), large eggs (Anger et al., 2002) at extrusion, and a strong increase in egg size during embryonic development (Table 1). The analyses of fecundity referred to all eggs independent of the embryonic development, due to few adult specimens available. Our fecundity estimates may therefore be biased by the high rates in egg losses during embryonic development, as demonstrated during hatching (Fig. 3). However, despite the females kept for rearing experiments of larvae, the eggs of all other preserved ovigerous females utilised had not reached the embryo stages IV to V yet. Since egg size increases dramatically in the very final stage of embryo development (Table 1), which obviously causes an increase of the entire batch, high amounts of egg losses may be typical of the hatching period only. In the final stage of embryo development, abdominal pleurae and pleopods do not cover the entire egg mass anymore, thus the less protected batch should be more sensitive to abrupt female behaviour and/or external physical impact.

Clarke (1993b) demonstrated a positive relationship between the extent of increase in egg size or volume and the level of nutrients stored in the eggs; this should indicate an enhanced female energy investment per offspring. However, egg size is not always a good indicator for nutrient contents, since nutrient contents of eggs may also be density dependent (Anger et al., 2002). From an evolutionary point of view, large larval size at 
hatching is commonly associated with an abbreviated mode of larval development (Thatje et al., 2001), which is advantageous in regions with short periods of primary production. Although low temperatures affect developmental rates negatively, a reduction in the number of larval moults reduces the energetic costs for larval development (Anger, 1998; Thatje et al., 2003a; Thatje et al., in press). Microscopical observations showed that the zoea I of $C$. vagans starts feeding immediately after hatching. On the other hand, starvation experiments indicated that the resistance of unfed larvae to nutritional stress is extremely high, extending the zoea I duration up to threefold. Some larvae which survived 3 weeks of starvation $(N=6)$ were re-fed and had retained the capability of reaching the moult to the subsequent zoeal stage. This indicates a very late appearance of a critical point, the point-of-no-return (Anger, 1987). This preliminary observation suggests that the zoea I of $C$. vagans contains high initial energy reserves, and recent investigation has shown that the larval energy supply in $C$. vagans mainly depends on proteins (Thatje et al., 2003b; Thatje et al., in press). These internal reserves alone, however, are insufficient to reach the moult to the zoea II stage in complete absence of food.

Larval sizes in the present study showed a clear discrepancy when compared with larvae from plankton catches obtained in the southwestern Atlantic Ocean (Thatje et al., 2001, zoea $\mathrm{I}, \mathrm{CL}=1.9 \mathrm{~mm}, \mathrm{TL}=5.8 \mathrm{~mm}$; zoea $\mathrm{II}, \mathrm{CL}=2.0 \mathrm{~mm}$, TL $=6.9 \mathrm{~mm}$ ). These striking differences should indicate that intraspecific variability is high, and may be correlated with female fitness and size. Plasticity in caridean larval developments was shown to be responsible for changes in larval size and developmental pathways in Nauticaris magellanica (Thatje and Bacardit, 2000; Wehrtmann and Albornoz, 2003), being temperature dependent. In addition, differences in larval developments between laboratory reared and field collected larvae were shown to be affected by rearing conditions (Wehrtmann and Albornoz, 2003). Both patterns may help to explain the observed size differences in larvae of $C$. vagans, since the study of fatty acid contents in both larvae and Artemia sp. nauplii, may suggest that utilisation of the Artemia by larvae of $C$. vagans is not optimal (Thatje et al., 2003b; Thatje et al., in press). Despite the great intraspecific variability at hatching, this may explain the much slower growth in our laboratory reared larvae (Table 2, zoea I to zoea II, about $2.1 \%$ ) when compared with previous work (zoea I to zoea II, about 19\%, see Thatje et al., 2001).

In subantarctic regions, we find decapod crustacean species with both planktotrophic and lecithotrophic modes of larval development. In the former category, however, there is a tendency towards a reduction of the larval phase and an increase in initial larval size (Thatje and Bacardit, 2000; Thatje et al., 2001). More abbreviated types of larval development typically imply lecithotrophy, often associated with behavioural changes such as demersal drifting rather than active planktonic swimming. Such patterns are typical for decapods in the Magellan region (Thatje et al., 2003a), although complete lecithotrophy was, so far, experimentally demonstrated only in larvae of lithodid crabs from this region (e.g., Lovrich et al., 2003).

Future research should focus on early life histories of Antarctic shrimp species, which should be still more adapted to conditions of cold and food limitation (see Clarke, 1977, 1993b; Gorny and George, 1997). If typical reproductive adaptations result in a partial or complete food-independent larval development in high latitudes, we should expect to find 
large sizes and a high initial lipid content of the eggs and larvae, an abbreviated larval development, and a high degree of endotrophy.

\section{Acknowledgements}

We are grateful to the International Bureau of the German Ministry of Research (BMBF, Project No. IB Arg 99/002) and the Argentine Secretaría Nacional para la Tecnología, Ciencia e Inovación Productiva (SETCIP) for continuous financial support of this bilateral co-operation during the last years. Thanks are due to Marcelo Gutierrez for assistance in the field. Federico Tapella provided the map on the study area. This work was partially funded by the Alfred Wegener Institute for Polar and Marine Research, Bremerhaven, Germany. The improvements of an earlier draft by the detailed comments of two anonymous reviewers are greatly acknowledged. [RW]

\section{References}

Abele, L.G., 1982. Biogeography. In: Abele, L.G. (Ed.), The Biology of Crustacea: 1.1. Systematics, the Fossil Record and Biogeography. Academic Press, New York, pp. 242-304.

Anger, K., 1987. The $\mathrm{D}_{\mathrm{o}}$ threshold: a critical point in the larval development of decapod crustaceans. J. Exp. Mar. Biol. Ecol. 108, 15-30.

Anger, K., 1998. Patterns of growth and chemical composition in decapod crustacean larvae. Invertebr. Reprod. Dev. 33, 159-176.

Anger, K., Moreira, G.S., Ismael, D., 2002. Comparative size, biomass, chemical composition (C, N, H) and energy concentration of caridean shrimp eggs. Invertebr. Reprod. Dev. 32, 83-93.

Arntz, W.E., Brey, T., Gerdes, D., Gorny, M., Gutt, J., Hain, S., Klages, M., 1992. Patterns of life history and population dynamics of benthic invertebrates under the high Antarctic conditions of the Weddell Sea. In: Colombo, G., Ferrari, I., Ceccherelli, V.U., Rossi, R. (Eds.), Marine Eutrophication and Population Dynamics: Proceedings of the 25th European Marine Biology Symposium. Olsen \& Olsen, Fredensborg, Denmark, pp. $221-230$

Bauer, R.T., 1989. Continuous reproduction and episodic recruitment in nine shrimp species inhabiting a tropical seagrass meadow. J. Exp. Mar. Biol. Ecol. 127, 175-187.

Briggs, J.C., 1995. Global Biogeography Elsevier, Amsterdam.

Clarke, A., 1977. A preliminary investigation of the lipids of Chorismus antarcticus (Pfeffer) (Crustacea, Decapoda) at South Georgia. In: Llano, G.A. (Ed.), Adaptations within Antarctic Ecosystems. Proceedings of the 3rd SCAR Symposium of Antarctic Biology. Smithsonian Institution, Washington, DC, pp. 343-350.

Clarke, A., 1982. Temperature and embryonic development in polar marine invertebrates. Int. J. Invertebr. Reprod. 5, 71-82.

Clarke, A., 1987. Temperature, latitude and reproductive effort. Mar. Ecol. Prog. Ser. 38, 89-99.

Clarke, A., 1993a. Reproductive trade-offs in caridean shrimps. Funct. Ecol. 7, 411-419.

Clarke, A., 1993b. Egg size and egg composition in polar shrimps (Caridea; Decapoda). J. Exp. Mar. Biol. Ecol. $168,189-203$.

Clarke, A., Lakhani, K.H., 1979. Measures of biomass, moulting behaviour and the pattern of early growth in Chorismus antarcticus (Pfeffer). Bull. - Br. Antarct. Surv. 47, 61-68.

Gorny, M., 1999. On the biogeography and ecology of the Southern Ocean decapod fauna. Sci. Mar. 63 (Suppl. 1), $367-382$.

Gorny, M., George, M.R., 1997. Oocyte development and gonad production of Nematocarcinus lanceopes (Decapoda: Caridea) in the eastern Weddell Sea, Antarctica. Polar Biol. 17, 191-198.

Gorny, M., Arntz, W.E., Clarke, A., Gore, D.J., 1992. Reproductive biology of caridean decapods from the Weddell Sea. Polar Biol. 12, 111-120.

Gorny, M., Brey, T., Arntz, W., Bruns, T., 1993. Growth, development and productivity of Chorismus antarcticus 
(Pfeffer) (Crustacea: Decapoda: Natantia) in the eastern Weddell Sea, Antarctica. J. Exp. Mar. Biol. Ecol. 174, $261-275$.

Kirkwood, J.M., 1984. A guide to the Decapoda of the Southern Ocean. ANARE Res. Notes 11, 1-47.

Lovrich, G.A., 1999. Seasonality of larvae of Brachyura and Anomura (Crustacea Decapoda) in the Beagle Channel, Argentina. Sci. Mar. 63 (Suppl. 1), 347-354.

Lovrich, G.A., Thatje, S., Calcagno, J.A., Anger, K., Kaffenberger, A., 2003. Changes in biomass and chemical composition during lecithotrophic larval development of the Southern king crab Lithodes santolla (Molina). J. Exp. Mar. Biol. Ecol. 288, 65-79.

Pérez-Barros, P., Tapella, F., Romero, M.C., Calcagno, J.A., Lovrich, G.A., in press. Benthic decapod crustaceans associated to captures of Munida spp. (Decapoda: Anomura) in the Beagle Channel, Argentina. Sci. Mar.

Pike, R.B., Williamson, D.I., 1966. The first zoeal stage of Campylonotus rathbunae Schmitt and its bearing on the systematical position of the Campylonotidae (Decapoda, Caridea). Trans. R. Soc. N. Z., Zool. 7, $209-213$.

Reid, D.M., Corey, S., 1991. Comparative fecundity of decapod crustaceans: III. The fecundity of fifty-three species of Decapoda from tropical, subtropical, and boreal waters. Crustaceana 61, 308-316.

Sokal, R.R., Rohlf, F.J., 1995. Biometry, The Principles and Practice of Statistics in Biological Research. Freeman, New York, pp. 1-887.

Tapella, F., Lovrich, G.A., Romero, M.C., Thatje, S., 2002. Reproductive biology of the crab Munida subrugosa (Decapoda: Anomura: Galatheidae) in the Beagle Channel, Argentina. J. Mar. Biol. Assoc. U.K. 82, 589-595.

Thatje, S., 2003. Campylonotus arntzianus, a new species of the Campylonotidae (Crustacea: Decapoda: Caridea) from the Scotia Sea (Antarctica). Polar Biol. 26, 242-248.

Thatje, S., Bacardit, R., 2000. Morphological variability in larval stages of Nauticaris magellanica (A. Milne Edwards, 1891) (Decapoda: Caridea: Hippolytidae) from South American waters. Bull. Mar. Sci. 66, $375-398$.

Thatje, S., Lovrich, G.A., 2003. Decapodid and early juvenile development in the protandrous shrimp Campylonotus vagans Bate, 1888 (Crustacea: Decapoda: Caridea), with notes on larval morphology. J. Mar. Biol. Assoc. U.K. 83 (1), $103-109$.

Thatje, S., Mutschke, E., 1999. Macrofauna bentónica muestreada con un Reineck box corer. Resultados Crucero Cimar-Fiordo 3 Comite Oceanográf. Nac. Valparaíso, Chile, pp. 126-128.

Thatje, S., Bacardit, R., Romero, M.C., Tapella, F., Lovrich, G.A., 2001. Description and key to the zoeal stages of the Campylonotidae (Decapoda, Caridea) from the Magellan Region. J. Crustac. Biol. 21, 492-505.

Thatje, S., Lovrich, G.A., Torres, G., Hagen, W., Anger, K., in press. Changes in biomass, lipid, fatty acid and elemental composition during the abbreviated larval development of the subantarctic shrimp Campylonotus vagans. J. Exp. Mar. Biol. Ecol.

Thatje, S., Calcagno, J.A., Lovrich, G.A., Sartoris, F.J., Anger, K., 2003a. Extended hatching periods in the Subantarctic lithodid crabs Lithodes santolla and Paralomis granulosa (Crustacea: Decapoda). Helgol. Mar. Res. 57, 110-113.

Thatje, S., Schiel, S., Arntz, W.E., 2003b. Developmental trade-offs in Subantarctic meroplankton communities and the enigma of low decapod diversity of high southern latitudes. Mar. Ecol. Prog. Ser. 60, 195-207.

Tiefenbacher, L., 1990. Eualus kinzeri, a new hippolytid shrimp from the Weddell Sea (Antarctica) (Crustacea: Decapoda: Natantia). Spixiana 13, 117-120.

Torti, M.R., Boschi, E.E., 1973. Nuevos aportes al conocimiento de los crustáceos decápodos Caridea del genero Campylonotus Bate, 1888. Physis, Secc. A, Buenos Aires 32, 65-84.

Wehrtmann, I.S., Albornoz, L., 1998. Larval development of Nauticaris magellanica (A. Milne Edwards, 1891) (Decapoda: Caridea: Hippolytidae), reared under laboratory conditions. Bull. Mar. Sci. 62, 45-72.

Wehrtmann, I.S., Albornoz, L., 2003. Morphological variability in the development of laboratory-reared Nauticaris magellanica (Decapoda: Caridea: Hippolytidae) larvae, with comparison to larvae collected from the plankton. J. Mar. Biol. Ass. U.K. 83, 949-957.

Wehrtmann, I.S., Kattner, G., 1998. Changes in volume, biomass, and fatty acids of developing eggs in Nauticaris magellanica (Decapoda: Caridea): a latitudinal comparison. J. Crustac. Biol. 18, 413-422.

Wehrtmann, I.S., Lardies, M.A., 1996. Species composition and geographical distribution of caridean shrimps (Decapoda: Caridea). In: Arntz, W., Gorny, M. (Eds.), Cruise Report of the Joint Chilean-German-Italian Magellan "Victor Hensen” Campaign in 1994. Rep. Polar Res. 190, 63-67. 
Wehrtmann, I.S., Lardies, M.A., 1999. Egg production of Austropandalus grayi (Decapoda, Caridea, Pandalidae) from the Magellan region, South America. Sci. Mar. 63 (Suppl. 1), 325-331.

Yaldwyn, J.C., 1965. Antarctic and subantarctic decapod crustacea. In: van Mieghem, J., van Oye, P. (Eds.), Biogeography and Ecology in the Antarctic. W. Junk Publ., The Hague, pp. 324-332.

Yaldwyn, J.C., 1966. Protandrous hermaphroditism in decapod prawns of the families Hippolytidae and Campylonotidae. Nature 209, 1366. 